\title{
Effect of Plant Geometry and Nutrition on Growth, Parameters of Transplanted Ajowan (Trachyspermum ammi L. Sprague) in the Red Loamy Soils of Andhra Pradesh, India
}

\author{
H. S. Kiran, M. Lakshminarayana Reddy, K. Giridhar, S. Surya Kumari \\ and D. R. Salomi Suneetha
}

College of Horticulture, Venkataramannagudem, West Godavari dist., Andhra Pradesh, India

*Corresponding author

\section{Keywords}

Transplanted Ajowan, plant geometry, NPK, nutrition, growth

Article Info

Accepted:

11 June 2020

Available Online:

10 July 2020

\begin{abstract}
A B S T R A C T
The present investigation entitled Effect of plant geometry and nutrition on growth parameters of transplanted ajowan (Trachyspermum ammi L. Sprague) in the red loamy soils of Andhra Pradesh. was carried out at College of Horticulture, Venkataramannagudem, West Godavari district of Andhra Pradesh during Rabi 2017-2018. The experiment was laid out in a factorial randomized block design with 18 treatments replicated thrice. The treatments include plant geometries $30 \mathrm{~cm} \mathrm{x} 20 \mathrm{~cm}, 45 \mathrm{~cm}$ x $20 \mathrm{~cm}$ and $30 \mathrm{~cm}$ x $30 \mathrm{~cm}$ at six fertilizer levels i.e. 75\% RDF (15: 30:15 NPK kg hectare $\mathrm{e}^{-1}$ ), 100\% RDF (20: 40:20 NPK kg hectare ${ }^{-1}$ ), 125\% RDF (25: $50: 25$ NPK kg hectare ${ }^{-1}$ ), 150\% RDF (30: 60: 30 NPK kg hectare ${ }^{-1}$ ), 175\% RDF (35: 70: 35 NPK kg hectare ${ }^{-1}$ ), and 200\% RDF (40: 80: 40 NPK $\left.\mathrm{kg} \mathrm{hectare}^{-1}\right)$.Among the different fertilizer levels and plant geometry number of primary branches (14.90) and secondary branches (59.67), fresh weight (143.67 g) and dry weight per plant (48.67 g) significantly higher in the fertilizer level $200 \%$ RDF with plant geometry $45 \mathrm{~cm}$ x $20 \mathrm{~cm}$ whereas plant height shows significantly higher $(118.67 \mathrm{~cm})$ in the fertilizer level $200 \%$ RDF with the plant geometry $30 \mathrm{~cm} \times 20 \mathrm{~cm}$ and plant spread $\left(181 \mathrm{~cm}^{2}\right)$ in the fertilizer level $200 \%$ RDF with plant geometry $30 \mathrm{~cm} \mathrm{x} 30 \mathrm{~cm}$, crop growth rate $\left(12.20 \mathrm{~g} \mathrm{dm}^{2} \mathrm{day}^{-1}\right)$ at $175 \%$ RDF with plant geometry 30 $\mathrm{cm} \times 20 \mathrm{~cm}$ but plant population after 30,60 and 90 days found non-significant.
\end{abstract}

\section{Introduction}

Ajowan or Bishop's weed (Trachyspermum ammi L. Sprague) is an annual herb belonging to the family Apiaceae. It originated in the Central Asiatic and Abyssinian regions (Vavilov and Dorofeev, 1992). It is cultivated in the Mediterranean region and in South West Asian countries such as Iraq, Iran, Afghanistan, Pakistan and India. In India, it is cultivated on a commercial scale in the states of Rajasthan, Gujarat, Uttar Pradesh,
Haryana, Punjab, Andhra Pradesh and West Bengal. Since the crop is generally grown in small patches, authentic data regarding the area under its cultivation and the production are not available.

However, in India it is estimated that, production was to the extent of 16 thousand tons with an area of 24 thousand hectares during the year 2016-17 (NHB 2016). Ajowan fruits are consumed as spice because of its characteristic aroma and pungent taste. 
It is known as adjuncts, used in small quantities for flavouring the numerous food as antioxidant and also as a preservative in confectionary, beverages and pan mixtures. Ajowan is used as a household remedy for indigestion and it is much valued for its antispasmodic stimulant, tonic and carminative properties. It is administered in flatulence, dyspepsia, diarrhoea and often recommended for cholera. Ajowan is also effective in relaxing sore throat and in bronchitis and often as an ingredient of cough mixtures. The paste of crushed fruits is applied externally for relieving colic pains. The roots of ajowan plant are reported to possess diuretic and carminative properties and are used in febrile conditions and in stomach disorders.

Scientific information on the effect of plant geometry and nutrition of ajowan is lacking especially in the red loamy soils of Andhra Pradesh. Geometry is an important factor for better growth and yield of the plant. Optimum number of plants is required per unit area to utilize the available production factors efficiently such as water, nutrient, light and $\mathrm{CO}_{2}$. Normally, maximum yields are obtained from plant populations which do not allow plants to achieve their individual maximum potential of the vegetative growth. Thus, the entire community of plants considered for higher production rather than individual plant performance (Donald, 1963)

Application of $\mathrm{N}$ promotes higher photosynthetic activity and vigorous vegetative growth and as a result, the plants turn into dark green colour (Balasubramaniyan and Palaniappan, 2005). Phosphorus, being the constituent of nucleic acid, phospholipids, is also very essential for proper development of crops. It imparts hardness to shoot, improves grain quality, regulates photosynthesis, governs physicochemical processes, help in the enlargement of cell and develop resistant to diseases. Potassium plays a major role in transport of water and nutrients throughout the plant in xylem and improves drought tolerance to plants (Reddy and Reddi, 2002).

\section{Materials and Methods}

An experiment was conducted in college of horticulture, Venkataramannagudem during the rabi season, 2017-2018. This experiment was laid out in factorial randomized block design with 3 replications and 18 treatments. Two factors include 6 levels of fertilizers [15:30:15 NPK Kg ha ${ }^{-1}\left(\mathrm{~F}_{1}\right), 20: 40: 20 \mathrm{NPK}$ $\mathrm{Kg} \mathrm{ha}{ }^{-1}\left(\mathrm{~F}_{2}\right), \quad 25: 50: 25$ NPK Kg ha- ${ }^{-1}\left(\mathrm{~F}_{3}\right)$, 30:60:30 NPK Kg ha ${ }^{-1}\left(\mathrm{~F}_{4}\right)$, 35:70:35 NPK Kg $\mathrm{ha}^{-1}\left(\mathrm{~F}_{5}\right)$ and 40:80:40 NPK Kg ha ${ }^{-1}\left(\mathrm{~F}_{6}\right)$ and Spacings $\left[30 \mathrm{~cm} \times 20 \mathrm{~cm}\left(\mathrm{~S}_{1}\right), 45 \mathrm{cmx} 20 \mathrm{~cm}\right.$ $\left.\left(S_{2}\right), 30 \mathrm{~cm} \times 30 \mathrm{~cm}\left(S_{3}\right)\right]$. Different level of fertilizers applied according to the treatments with suitable spacings, Nitrogen and Potassium applied at 30, 60 and 90 days whereas Phosphorous applied as basic dose.

Random selection of five plants per plots for recorded the characters likeplant height $(\mathrm{cm})$, number of primary branches per plant, number of secondary branches per plant, plant spread $\left(\mathrm{cm}^{2}\right)$, fresh weight of plant, above ground dry weight of plant $(\mathrm{g})$, crop growth rate at $60,90,120$ days after sowing.Data recorded on growth, yield and quality parameter was subjected to analysis of variance (ANOVA, $\mathrm{p} \leq 0.05$ ) and means comparisons were done at $P \leq 0.05$.

\section{Results and Discussion}

\section{Plant height (cm)}

The data pertaining to plant height in ajowan on different fertilizer levels and plant geometry are presented in Table 1 and fig 1 . The differences among the fertilizer levels, plant geometry and their interaction for plant 
height were found significant at all three dates of observations recorded at 30 and 90 DAT, respectively. The plant height was significantly higher in $(60.62,86$ and $112 \mathrm{~cm})$ at 30, 60 and 90 DAT, respectively at with application of 200\% RDF (40:80:40 NPK kg $\mathrm{ha}^{-1}$ ) followed by $175 \%$ RDF (35:70:35 NPK $\left.\mathrm{kg} \mathrm{ha}^{-1}\right)(56.88,83.22$ and $107.00 \mathrm{~cm})$ at 30 , 60 and 90 DAT, respectively. The minimum plant height was recorded (47.64, 71 and $90.11 \mathrm{~cm}$ ) at 30, 60 and 90 DAT, respectively at $75 \% \mathrm{RDF}$.

Among different plant geometries evaluated, significantly increased plant height was recorded $(56.29,80.58$ and $101.94 \mathrm{~cm}$, respectively at 30, 60 and 90 DAT) at $30 \mathrm{~cm} \mathrm{x}$ $20 \mathrm{~cm}$. The plant geometry of $45 \mathrm{~cm} \times 20 \mathrm{~cm}$ recorded significantly lowest plant height $(50.75,76.61$ and $95.39 \mathrm{~cm})$ at all the stages of observations.

The interaction effect among different fertilizer levels and different plant geometries with respect to plant height was found to be significant. Maximum plant height of 64.60, 87.33 and $118.67 \mathrm{~cm}$ at 30,60 and 90 DAT, respectively was recorded at $200 \% \mathrm{RDF}$ (40:80:40 NPK kg ha ${ }^{-1}$ ) with plant geometry $30 \mathrm{~cm} \times 20 \mathrm{~cm}$ and minimum plant height was observed (47.27, 70.33 and $89.33 \mathrm{~cm}$ at 30,60 and 90 DAT respectively) with $75 \% \mathrm{RDF}$ (15:30:15 NPK kg ha $\left.{ }^{-1}\right)$ at $45 \times 20 \mathrm{~cm}$.

It was observed that plant height was highest when it was grown under closer plant geometry compared to wider plant geometry due to mutual shading and higher population density. This might have decreased availability of sun light to the plant. The reduced light intensity at the base of the plant stem might have accelerated elongation of lower internodes resulting in increased plant height. The observed crop behavior under closer spacing is in close conformity with the findings of Donald (1963) who reported that in many crops up to a certain level of population, plant elongates rapidly due to mutual shading but beyond this, elongation is checked due to reduced availability of photosynthates. These observations are in also close conformity with findings of Naruka et al., (2012) in ajowan.

\section{Number of primary branches}

The data pertaining to number of primary branches is furnished in Table 2. It showed significant differences were observed among different fertilizer levels, plant geometry and their interaction.

The perusal of data of number of primary branches indicated that significantly more number of primary branches was observed with the application of $200 \%$ RDF (40:80:40 NPK kg ha $\left.{ }^{-1}\right)$ found $(4.24,10.31$ and 14.53) at 30, 60 and It was observed that among different plant geometries, at all stages of observation significantly higher number of primary branches was recorded $(3.88,8.73$ and 12.66 at 30, 60 and 90 DAT, respectively) at $45 \mathrm{~cm} \times 20 \mathrm{~cm}$ over the other plant geometries evaluated.

Among interaction effects at 30 DAS, the fertilizer application of $200 \%$ RDF with plant geometry $45 \mathrm{~cm} \times 20 \mathrm{~cm}$ (4.87) recorded significantly higher number of branches over other combinations. At 60 DAS, the fertilizer application of 200\% RDF (40:80:40 NPK kg $\mathrm{ha}^{-1}$ ) with plant geometry $45 \mathrm{~cm} \mathrm{x} 20 \mathrm{~cm}$ (10.4) recorded significantly higher number of branches followed by $200 \%$ RDF (40:80:40 NPK kg ha ${ }^{-1}$ ) with $30 \mathrm{~cm} \mathrm{x} 20 \mathrm{~cm}$ plant geometry (10.2) which were on par with each other and significantly higher over other combinations. At $90 \mathrm{DAS}$, the fertilizer application of 200\% (40:80:40 NPK kg ha-1) RDF with plant geometry $45 \mathrm{~cm} \times 20 \mathrm{~cm}$ (14.9) recorded significantly higher number of branches over other combinations. 
The results indicated that crop raised under wider spacing recorded highest number of primary branches. Significant improvement in aforesaid parameter in lower plant densities was due to availability of more area per plant which implied that individual plant at wider spacing received higher growth inputs (sunlight, water and nutrients) with least competition resulting in larger canopy as compared to the plants in higher densities. Significant improvement in growth with increase in spacing is in close conformity with the findings of Yadav et al., (2002) in fennel, Krishnamurthy et al., (2000), Premnath et al., (2008) and Naruka et al., (2012) in ajowan.

\section{Number of secondary branches}

The data of number of secondary branches is presented in Table 3 and fig 2. Regarding number of secondary branches, it was found that the effect of fertilizer application, plant geometry and their interaction were found significant. The data indicated that among the fertilizer doses evaluated, at all stages of observation, significantly higher of number of secondary branches $(21.73,34.64$ and 51.78 at 30,60 and 90 DAT respectively) were observed with fertilizer application at $200 \%$ RDF (40:80:40 NPK kg ha' ${ }^{-1}$ ).

Similarly, at all stages of observation, significantly higher number of secondary branches was noticed with $45 \mathrm{~cm} \times 20 \mathrm{~cm}$ (20.04, 30.51 and 45.17 at 30, 60 and 90 DAT, respectively) plant geometry over two other plant geometries.

Among the interactions between fertilizer levels and plant geometry, the number of secondary branches was significantly higher with the fertilizer application of found $200 \%$ RDF (40:80:40 NPK $\mathrm{kg} \mathrm{ha}^{-1}$ ) with plant geometry $45 \mathrm{~cm} \times 20 \mathrm{~cm}(28.33,39.33$ and 59.67 at 30, 60 and 90 DAT, respectively) over all other combinations.
The results indicated that irrespective of fertilizer dose, crop raised under wider spacing recorded highest number of secondary branches. Significant improvement in aforesaid parameter was due to increase in higher availability of space, sunlight, water and nutrients. Further, reduced inter-plant competition might have helped the plant to put forth better growth when compared with the plant geometry where more plants were accommodated in unit area.

The improvement in secondary branches with higher doses of fertilizer and wider spacing was probably due to low inter-plant completion and greater availability of macronutrients to the plants. Similar result was reported by Jenny et al., (2006) in ajowan crop.

\section{Plant spread $\left(\mathrm{cm}^{2}\right)$}

Appraisal of data (Table 4) revealed that significant effect of application of different fertilizer levels, plant geometry and their combinations on plant spread. At all stages of observation, among the fertilizer doses evaluated, significantly higher plant spread was recorded with $(100.89,138.33$ and $172.78 \mathrm{~cm}^{2}$ at 30,60 and 90 DAT, respectively) were observed with the fertilizer application of 200\% RDF (40:80:40 NPK kg $\mathrm{ha}^{-1}$ ).

Among the plant geometries, significantly higher plant spread was noticed with $30 \mathrm{~cm}$ x $30 \mathrm{~cm}$ plant geometry $(94.33,130.11$ and $167.94 \mathrm{~cm}^{2}$ at 30,60 and 90 respectively) over two other plant geometries. Regarding the interaction between fertilizer levels and plant geometry, the plant spread was significantly higher with the fertilizer application of found $200 \%$ RDF with plant geometry $30 \mathrm{~cm}$ x $30 \mathrm{~cm} \mathrm{107,145.33} \mathrm{and} 181$ $\mathrm{cm}^{2}$ at 30, 60 and 90 days, respectively) over all other combinations. 
The above result indicated that plants were grown under plant geometry having equal row to row and plant to plant spacing have more plant spread due to better interception of sunlight and same amount of nutrient, water and sunlight will be available to all the plants and with increased dose of fertilizer there will be increase in plant spread due more number of primary and secondary branches. Comparable results were found by Sathyanarayana et al., (2015) and Premnath et al., (2008) in ajowan crop.

\section{Fresh weight (g)}

It is evident from the Table 5 that with change in plant geometry or fertilizer dose applied; there was corresponding change in fresh weight. It was also observed that the interaction effect of different fertilizer doses and plant geometry on fresh weight of plant was also significant.

It is evident from the data that the fresh weight was significantly higher with the fertilizer application of $200 \% \mathrm{RDF}$ at 30 and 90 DAT (61.72 and $137 \mathrm{~g}$ at 30 and 90 DAT, respectively). However, at $60 \mathrm{DAT}$, the fertilizer doses of 200\% RDF (40:80:40 NPK $\mathrm{kg} \mathrm{ha}^{-1}$ ) and 150\% RDF (30:60:30 NPK kg $\left.\mathrm{ha}^{-1}\right)$ (80.89 $\mathrm{g}$ and $82.67 \mathrm{~g}$, respectively) were at par and significantly superior over other levels of fertilizer.

Regarding plant geometries, at 30 DAT, maximum fresh weight was recorded with plant geometry $45 \mathrm{~cm} \times 20 \mathrm{~cm}(54.72 \mathrm{~g})$ at followed by $(52.71 \mathrm{~g})$ at $30 \mathrm{~cm} \times 30 \mathrm{~cm}$ which were on par with each other and significantly superior to $30 \mathrm{~cm} \times 20 \mathrm{~cm}$. However, at 60 DAT and 90 DAT, significantly maximum fresh weight was recorded (80.17 and 131.56 $\mathrm{g}$ at 60 and 90 DAT, respectively) at $45 \mathrm{~cm} \mathrm{x}$ $20 \mathrm{~cm}$. Among the interaction effects between the fertilizer levels and plant geometry and it was observed that significantly higher fresh weight (69.00 and $143.67 \mathrm{~g}$ at 30 and 90 DAT, respectively) was recorded with at 200\% RDF (40:80:40 NPK kg ha ${ }^{-1}$ ) with plant geometry $45 \mathrm{~cm} \times 20 \mathrm{~cm}$. However, at 60 DAT, the maximum fresh weight was recorded with the fertilizer application of 200\% RDF (40:80:40 NPK kg ha ${ }^{-1}$ ) and plant geometry $45 \mathrm{~cm} \times 20 \mathrm{~cm}$. The results indicated that plant grown under wider plant geometry leads to larger canopy development associated with increased plant height, profuse branching and canopy spread which helped in increased interception, absorption and utilization of solar energy resulting in formation of higher photosynthates and finally dry matter per plant.

The improvement in morphological parameters under the influence of NPK application might have resulted in larger canopy development and presumably higher chlorophyll content of leaves as nutrient actively participate in its formation. The findings of this investigation are in accordance with the conclusion drawn by Krishnamoorthy and Madalageri (2002), Premnath et al., (2008), Naruka et al., (2012) in ajowan.

\section{Dry weight (g)}

The data pertaining to dry weight is presented in Table 6. There was significant increase in dry weight with different fertilizers levels, plant geometry and their interaction. The results obtained indicated that significantly higher dry weight was recorded with the fertilizer application of 200\% RDF (40:80:40 NPK kg ha ${ }^{-1}$ ) (17.00 and $43.78 \mathrm{~g}$ at 30 and 90 DAT, respectively). However, at 60 DAT, significantly higher dry weight was recorded with the fertilizer application of $200 \%$ RDF $(26.00 \mathrm{~g})$ followed by the application of $175 \%$ RDF (23.56 g) which were on par with each other and significantly superior to all other fertilizer levels. 
Table.2 Effect of fertilizer levels (F) and plant geometry(S) on number of primary branches per plant in ajowan

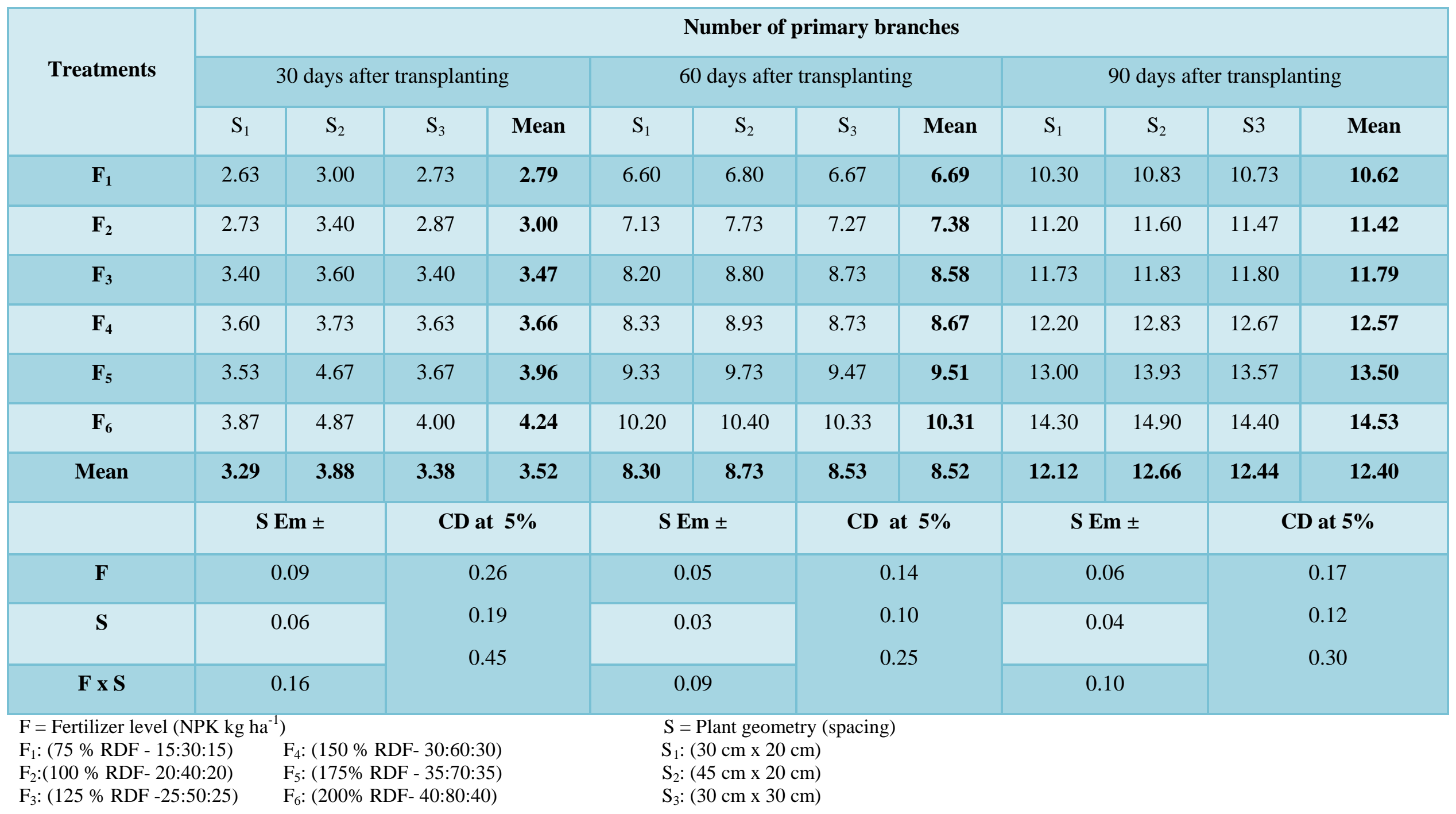


Table.3 Effect of fertilizer levels (F) and plant geometry (S) on number of secondary branches per plant in ajowan

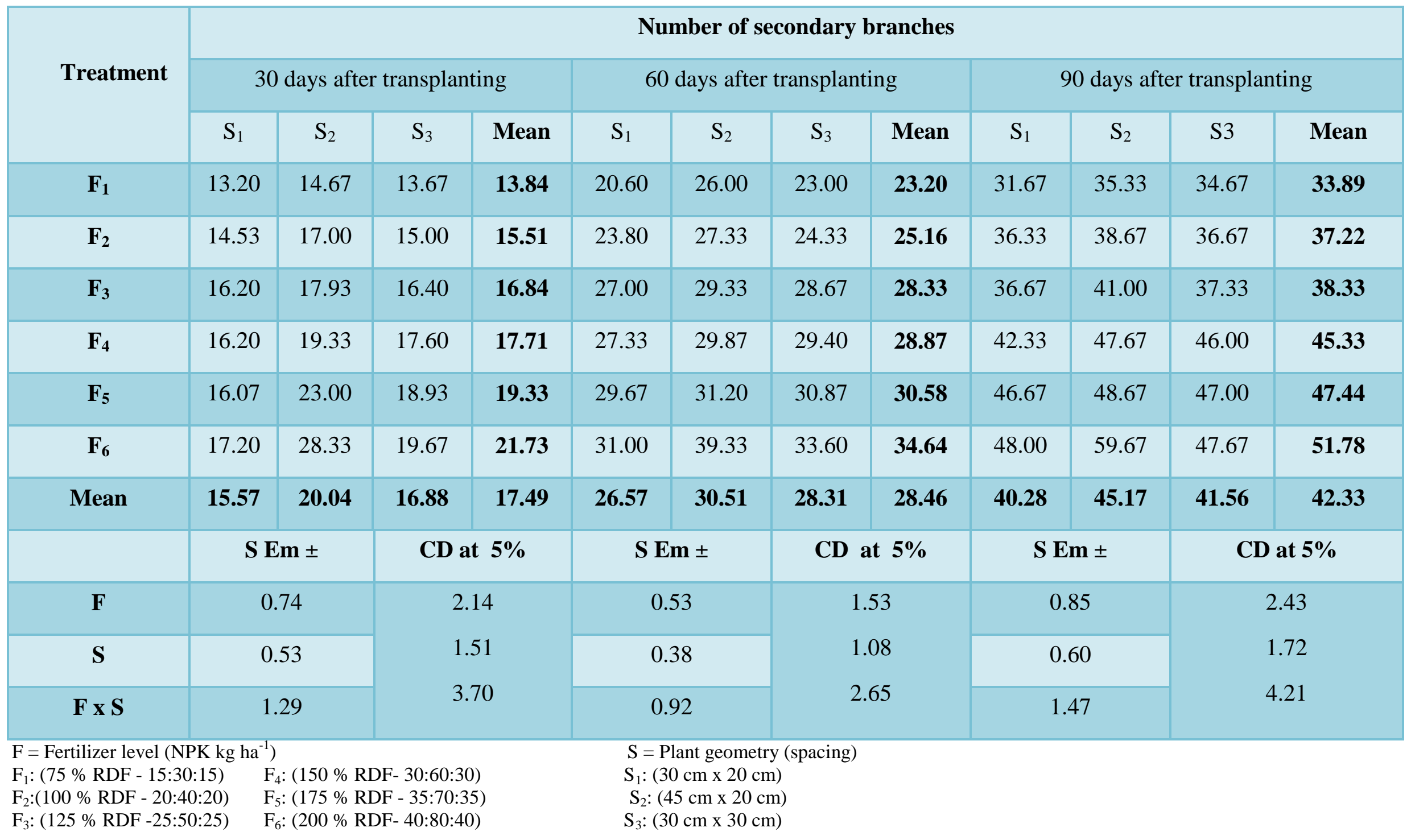


Table.4 Effect of fertilizer levels (F) and plant geometry (S) on plant spread in ajowan

\begin{tabular}{|c|c|c|c|c|c|c|c|c|c|c|c|c|}
\hline \multirow{3}{*}{ Treatments } & \multicolumn{12}{|c|}{ Plant spread $\left(\mathrm{cm}^{2}\right)$} \\
\hline & \multicolumn{4}{|c|}{30 days after transplanting } & \multicolumn{4}{|c|}{60 days after transplanting } & \multicolumn{4}{|c|}{90 days after transplanting } \\
\hline & $\mathrm{S}_{1}$ & $\mathrm{~S}_{2}$ & $\mathrm{~S}_{3}$ & Mean & $\mathrm{S}_{1}$ & $\mathrm{~S}_{2}$ & $\mathrm{~S}_{3}$ & Mean & $\mathrm{S}_{1}$ & $\mathrm{~S}_{2}$ & $\mathrm{~S} 3$ & Mean \\
\hline $\mathbf{F}_{1}$ & 84.67 & 86.00 & 87.33 & 86.00 & 118.00 & 120.67 & 122.33 & 120.33 & 155.33 & 156.00 & 157.67 & 156.33 \\
\hline $\mathbf{F}_{2}$ & 88.33 & 87.00 & 90.00 & 88.44 & 121.67 & 122.00 & 125.67 & 123.11 & 158.67 & 161.67 & 164.67 & 161.67 \\
\hline $\mathbf{F}_{3}$ & 89.33 & 91.67 & 92.67 & 91.22 & 123.67 & 124.67 & 126.67 & 125.00 & 161.00 & 163.67 & 164.00 & 162.89 \\
\hline $\mathbf{F}_{4}$ & 91.67 & 93.33 & 94.00 & 93.00 & 126.67 & 128.00 & 127.33 & 127.33 & 163.33 & 166.33 & 167.67 & 165.78 \\
\hline $\mathbf{F}_{\mathbf{5}}$ & 93.00 & 94.33 & 95.00 & 94.11 & 128.00 & 129.00 & 133.33 & 130.11 & 164.00 & 170.00 & 172.67 & 168.89 \\
\hline $\mathbf{F}_{6}$ & 97.00 & 98.67 & 107.00 & 100.89 & 133.00 & 136.67 & 145.33 & 138.33 & 166.00 & 171.33 & 181.00 & 172.78 \\
\hline \multirow[t]{2}{*}{ Mean } & 90.67 & 91.83 & 94.33 & 92.27 & 125.17 & 126.83 & 130.11 & 127.37 & 161.39 & 164.83 & 167.94 & 164.72 \\
\hline & \multicolumn{2}{|c|}{$\mathrm{S} \mathbf{E m} \pm$} & \multicolumn{2}{|c|}{ CD at $5 \%$} & \multicolumn{2}{|c|}{$\mathrm{S} \mathbf{E m} \pm$} & \multicolumn{2}{|c|}{$\mathrm{CD}$ at $5 \%$} & \multicolumn{2}{|c|}{ S Em \pm} & \multicolumn{2}{|c|}{ CD at $5 \%$} \\
\hline $\mathbf{F}$ & \multicolumn{2}{|c|}{0.69} & \multirow{2}{*}{\multicolumn{2}{|c|}{$\begin{array}{l}1.99 \\
1.41\end{array}$}} & \multicolumn{2}{|c|}{0.83} & \multicolumn{2}{|c|}{2.38} & \multicolumn{2}{|c|}{0.97} & \multicolumn{2}{|c|}{2.78} \\
\hline $\mathbf{S}$ & \multicolumn{2}{|c|}{0.49} & & & \multicolumn{2}{|c|}{0.59} & \multicolumn{2}{|c|}{1.68} & & & \multicolumn{2}{|c|}{1.97} \\
\hline $\mathbf{F} \times \mathbf{S}$ & \multicolumn{2}{|c|}{1.20} & \multicolumn{2}{|c|}{3.45} & & & \multicolumn{2}{|c|}{4.12} & & & \multicolumn{2}{|c|}{4.81} \\
\hline \multicolumn{5}{|c|}{$\begin{array}{l}\mathrm{F}_{1}:(75 \% \mathrm{RDF}-15: 30: 15) \\
\mathrm{F}_{2}:(100 \% \mathrm{RDF}-20: 40: 20)\end{array}$} & & $\begin{array}{l}=\text { Plant ge } \\
(30 \mathrm{~cm} x \\
(45 \mathrm{~cm} x \\
(30 \mathrm{~cm} \mathrm{x}\end{array}$ & $\begin{array}{l}\text { etry (spad } \\
\mathrm{cm} \text { ) } \\
\mathrm{cm} \text { ) } \\
\mathrm{cm})\end{array}$ & & & & & \\
\hline
\end{tabular}


Table.5 Effect of fertilizer levels (F) and plant geometry (S) on fresh weight in ajowan

\begin{tabular}{|c|c|c|c|c|c|c|c|c|c|c|c|c|}
\hline \multirow{3}{*}{ Treatments } & \multicolumn{12}{|c|}{ Fresh weight (g plant ${ }^{-1}$ ) } \\
\hline & \multicolumn{4}{|c|}{30 days after transplanting } & \multicolumn{4}{|c|}{60 days after transplanting } & \multicolumn{4}{|c|}{90 days after transplanting } \\
\hline & $\mathrm{S}_{1}$ & $\mathrm{~S}_{2}$ & $\mathrm{~S}_{3}$ & Mean & $\mathrm{S}_{1}$ & $\mathrm{~S}_{2}$ & $\mathrm{~S}_{3}$ & Mean & $\mathrm{S}_{1}$ & $\mathrm{~S}_{2}$ & $\mathrm{~S} 3$ & Mean \\
\hline $\mathbf{F}_{1}$ & 43.67 & 47.67 & 45.67 & 45.67 & 67.00 & 78.00 & 69.00 & 71.33 & 119.67 & 122.33 & 121.00 & 121.00 \\
\hline $\mathbf{F}_{2}$ & 44.67 & 49.75 & 50.92 & 48.44 & 69.67 & 78.33 & 73.00 & 73.67 & 124.33 & 125.33 & 126.00 & 125.22 \\
\hline $\mathbf{F}_{\mathbf{3}}$ & 51.00 & 51.08 & 51.00 & 51.03 & 72.33 & 79.00 & 76.33 & 75.89 & 126.33 & 128.67 & 127.00 & 127.33 \\
\hline $\mathbf{F}_{4}$ & 53.67 & 54.42 & 54.00 & 54.03 & 75.00 & 80.33 & 79.33 & 78.22 & 128.00 & 133.67 & 132.67 & 131.44 \\
\hline $\mathbf{F}_{5}$ & 55.25 & 56.42 & 55.00 & 55.56 & 79.67 & 82.33 & 80.67 & 80.89 & 131.00 & 135.67 & 133.67 & 133.44 \\
\hline $\mathbf{F}_{6}$ & 56.50 & 69.00 & 59.67 & 61.72 & 82.33 & 83.00 & 82.67 & 82.67 & 133.00 & 143.67 & 134.33 & 137.00 \\
\hline \multirow[t]{2}{*}{ Mean } & 50.79 & 54.72 & 52.71 & 52.74 & 74.33 & 80.17 & 76.83 & 77.11 & 127.06 & 131.56 & 129.11 & 129.24 \\
\hline & \multicolumn{2}{|c|}{$\mathrm{S} \mathbf{E m} \pm$} & \multicolumn{2}{|c|}{ CD at $5 \%$} & \multicolumn{2}{|c|}{ S Em \pm} & \multicolumn{2}{|c|}{ CD at $5 \%$} & \multicolumn{2}{|c|}{ S Em \pm} & \multicolumn{2}{|c|}{ CD at $5 \%$} \\
\hline $\mathbf{F}$ & \multicolumn{2}{|c|}{1.04} & \multirow{2}{*}{\multicolumn{2}{|c|}{$\begin{array}{l}2.99 \\
2.11\end{array}$}} & \multicolumn{2}{|c|}{0.85} & \multicolumn{2}{|c|}{2.45} & \multicolumn{2}{|c|}{0.81} & \multicolumn{2}{|c|}{2.33} \\
\hline $\mathbf{S}$ & \multicolumn{2}{|c|}{0.73} & & & \multicolumn{2}{|c|}{0.60} & \multicolumn{2}{|c|}{1.73} & & & \multicolumn{2}{|c|}{1.65} \\
\hline $\mathbf{F} \times \mathbf{S}$ & \multicolumn{2}{|c|}{1.80} & \multicolumn{2}{|c|}{5.17} & & & \multicolumn{2}{|c|}{4.24} & & & \multicolumn{2}{|c|}{4.04} \\
\hline $\begin{array}{l}\mathrm{F}=\text { Fertilizer level } \\
\mathrm{F}_{1}:(75 \% \text { RDF - 15: } \\
\mathrm{F}_{2}:(100 \% \text { RDF: } 20: \\
\mathrm{F}_{3}:(125 \% \text { RDF - } 25\end{array}$ & $\begin{array}{l}\mathrm{K} \mathrm{kg} \mathrm{ha}^{-1} \\
15) \\
20) \\
25)\end{array}$ & $\begin{array}{c}(150 \% \\
(175 \% \\
(200 \%\end{array}$ & $\begin{array}{l}F-30: 60 \\
-35: 70 \\
\text { F- 40:80: }\end{array}$ & & & $\begin{array}{l}\text { lant geo } \\
0 \mathrm{~cm} \times 2 \\
5 \mathrm{~cm} \times 2 \\
0 \mathrm{~cm} \mathrm{x}\end{array}$ & $\begin{array}{l}\text { ry (spaci } \\
\text { m) } \\
\text { n) } \\
\text { m) }\end{array}$ & & & & & \\
\hline
\end{tabular}


Table.6 Effect of fertilizer levels (F) and plant geometry (S) on dry weight in ajowan

\begin{tabular}{|c|c|c|c|c|c|c|c|c|c|c|c|c|}
\hline \multirow{3}{*}{ Treatments } & \multicolumn{12}{|c|}{ Dry weight (g plant ${ }^{-1}$ ) } \\
\hline & \multicolumn{4}{|c|}{30 days after transplanting } & \multicolumn{4}{|c|}{60 days after transplanting } & \multicolumn{4}{|c|}{90 days after transplanting } \\
\hline & $\mathrm{S}_{1}$ & $\mathrm{~S}_{2}$ & $\mathrm{~S}_{3}$ & Mean & $\mathrm{S}_{1}$ & $\mathrm{~S}_{2}$ & $\mathrm{~S}_{3}$ & Mean & $\mathrm{S}_{1}$ & $\mathrm{~S}_{2}$ & $\mathrm{~S} 3$ & Mean \\
\hline $\mathbf{F}_{1}$ & 3.67 & 5.00 & 4.00 & 4.22 & 13.67 & 16.00 & 15.00 & 14.89 & 28.67 & 30.33 & 29.00 & 29.33 \\
\hline $\mathbf{F}_{2}$ & 6.00 & 8.33 & 7.00 & 7.11 & 15.00 & 17.33 & 16.67 & 16.33 & 31.67 & 33.00 & 32.00 & 32.22 \\
\hline $\mathbf{F}_{3}$ & 7.00 & 11.00 & 10.67 & 9.56 & 16.67 & 18.67 & 17.67 & 17.67 & 34.33 & 36.67 & 34.33 & 35.11 \\
\hline $\mathbf{F}_{4}$ & 10.67 & 13.00 & 12.33 & 12.00 & 18.00 & 20.00 & 19.33 & 19.11 & 37.67 & 38.00 & 37.33 & 37.67 \\
\hline $\mathbf{F}_{5}$ & 11.67 & 16.00 & 14.33 & 14.00 & 20.33 & 29.33 & 21.00 & 23.56 & 42.33 & 42.33 & 40.33 & 41.67 \\
\hline $\mathbf{F}_{6}$ & 14.00 & 21.33 & 15.67 & 17.00 & 21.33 & 34.00 & 22.67 & 26.00 & 40.33 & 48.67 & 42.33 & 43.78 \\
\hline \multirow[t]{2}{*}{ Mean } & 8.83 & 12.44 & 10.67 & 10.64 & 17.50 & 22.56 & 18.72 & 19.59 & 35.83 & 38.17 & 35.89 & 36.63 \\
\hline & \multicolumn{2}{|c|}{ S Em \pm} & \multicolumn{2}{|c|}{ CD at $5 \%$} & \multicolumn{2}{|c|}{$\mathrm{S} \mathbf{E m} \pm$} & \multicolumn{2}{|c|}{ CD at $5 \%$} & \multicolumn{2}{|c|}{$\mathrm{S} \mathbf{E m} \pm$} & \multicolumn{2}{|c|}{ CD at $5 \%$} \\
\hline $\mathbf{F}$ & \multicolumn{2}{|c|}{0.44} & \multirow{2}{*}{\multicolumn{2}{|c|}{$\begin{array}{l}1.27 \\
0.90\end{array}$}} & \multicolumn{2}{|c|}{1.06} & \multicolumn{2}{|c|}{3.04} & \multicolumn{2}{|c|}{0.62} & \multicolumn{2}{|c|}{1.79} \\
\hline $\mathbf{S}$ & \multicolumn{2}{|c|}{0.31} & & & \multicolumn{2}{|c|}{0.75} & \multicolumn{2}{|c|}{2.15} & & & \multicolumn{2}{|c|}{1.27} \\
\hline $\mathbf{F X S}$ & \multicolumn{2}{|c|}{0.77} & \multicolumn{2}{|c|}{2.21} & & & \multicolumn{2}{|c|}{5.26} & & & \multicolumn{2}{|c|}{3.11} \\
\hline \multicolumn{2}{|c|}{$\begin{array}{l}\mathrm{F}_{1}:(75 \% \text { RDF - } 15: 30: 15) \\
\mathrm{F}_{2}:(100 \% \text { RDF: } 20: 40: 20) \\
\mathrm{F}_{3}:(125 \% \text { RDF - 25:50:25) }\end{array}$} & $\begin{array}{l}-1) \\
F_{4}:(150 \\
F_{5}:(175 \\
F_{6}:(200\end{array}$ & $\begin{array}{l}\text { RDF- } 30 \\
\text { RDF }-3 \\
\text { RDF- } 40\end{array}$ & $\begin{array}{l}: 30) \\
: 35) \\
: 40)\end{array}$ & \multicolumn{4}{|c|}{$\begin{array}{l}\mathrm{S}_{1}:(30 \mathrm{~cm} \times 20 \mathrm{~cm}) \\
\mathrm{S}_{2}:(45 \mathrm{~cm} \times 20 \mathrm{~cm}) \\
\mathrm{S}_{3}:(30 \mathrm{~cm} \times 30 \mathrm{~cm})\end{array}$} & & & & \\
\hline
\end{tabular}


Table.7 Effect of fertilizer levels (F) and plant geometry (S) on crop growth rate in ajowan

\begin{tabular}{|c|c|c|c|c|c|c|c|c|c|c|c|c|}
\hline \multirow{3}{*}{ Treatments } & \multicolumn{12}{|c|}{ Crop growth rate $\left(\mathrm{g} \mathrm{dm}^{2} \mathrm{day}^{-1}\right)$} \\
\hline & \multicolumn{4}{|c|}{30 days after transplanting } & \multicolumn{4}{|c|}{60 days after transplanting } & \multicolumn{4}{|c|}{90 days after transplanting } \\
\hline & $\mathrm{S}_{1}$ & $\mathrm{~S}_{2}$ & $\mathrm{~S}_{3}$ & Mean & $\mathrm{S}_{1}$ & $\mathrm{~S}_{2}$ & $\mathrm{~S}_{3}$ & Mean & $S_{1}$ & $\mathrm{~S}_{2}$ & S3 & Mean \\
\hline $\mathbf{F}_{1}$ & 2.03 & 1.84 & 1.45 & 1.77 & 5.54 & 4.03 & 4.05 & 4.54 & 8.33 & 5.33 & 5.19 & 6.28 \\
\hline $\mathbf{F}_{2}$ & 3.32 & 3.09 & 2.59 & 3.00 & 5.00 & 3.32 & 3.59 & 3.97 & 8.21 & 5.75 & 5.67 & 6.54 \\
\hline $\mathbf{F}_{3}$ & 3.88 & 4.05 & 3.93 & 3.95 & 5.39 & 3.04 & 2.59 & 3.67 & 9.77 & 6.68 & 6.12 & 7.52 \\
\hline $\mathbf{F}_{4}$ & 5.89 & 4.78 & 4.54 & 5.07 & 3.97 & 2.63 & 2.59 & 3.06 & 10.92 & 6.67 & 6.70 & 8.10 \\
\hline $\mathbf{F}_{\mathbf{5}}$ & 6.44 & 5.90 & 5.30 & 5.88 & 4.83 & 4.96 & 2.48 & 4.09 & 12.20 & 4.78 & 7.19 & 8.05 \\
\hline $\mathbf{F}_{6}$ & 7.77 & 7.89 & 5.80 & 7.16 & 4.04 & 4.64 & 2.59 & 3.76 & 10.44 & 5.45 & 7.30 & 7.73 \\
\hline \multirow[t]{2}{*}{ Mean } & 4.89 & 4.59 & 3.94 & 4.40 & 4.80 & 3.77 & 2.98 & 3.83 & 9.98 & 5.78 & 6.36 & 7.37 \\
\hline & \multicolumn{2}{|c|}{ S Em \pm} & \multicolumn{2}{|c|}{ CD at $5 \%$} & \multicolumn{2}{|c|}{ S Em \pm} & \multicolumn{2}{|c|}{ CD at $5 \%$} & \multicolumn{2}{|c|}{ S Em \pm} & \multicolumn{2}{|c|}{ CD at $5 \%$} \\
\hline $\mathbf{F}$ & \multicolumn{2}{|c|}{1.89} & \multirow{2}{*}{\multicolumn{2}{|c|}{$\begin{array}{l}5.43 \\
3.84\end{array}$}} & \multicolumn{2}{|c|}{0.43} & \multicolumn{2}{|c|}{1.23} & \multicolumn{2}{|c|}{0.51} & \multicolumn{2}{|c|}{1.46} \\
\hline $\mathbf{S}$ & \multicolumn{2}{|c|}{1.34} & & & \multicolumn{2}{|c|}{0.30} & \multicolumn{2}{|c|}{0.87} & & & \multicolumn{2}{|c|}{1.03} \\
\hline F X S & \multicolumn{2}{|c|}{3.27} & \multicolumn{2}{|c|}{9.40} & & & \multicolumn{2}{|c|}{2.12} & & & \multicolumn{2}{|c|}{2.52} \\
\hline \multicolumn{2}{|c|}{$\begin{array}{l}\mathrm{F}_{1}:(75 \% \text { RDF - 15:30:15) } \\
\mathrm{F}_{2}:(100 \% \text { RDF: } 20: 40: 20) \\
\mathrm{F}_{3}:(125 \% \mathrm{RDF}-25: 50: 25)\end{array}$} & \multicolumn{3}{|c|}{$\begin{array}{l}\mathrm{F}_{4}:(150 \% \text { RDF- 30:60:30) } \\
\mathrm{F}_{5}:(175 \% \text { RDF - 35:70:35) } \\
\mathrm{F}_{6}:(200 \% \text { RDF- 40:80:40) }\end{array}$} & \multicolumn{3}{|c|}{$\begin{array}{l}\mathrm{S}_{1}:(30 \mathrm{~cm} \times 20 \mathrm{~cm}) \\
\mathrm{S}_{2}:(45 \mathrm{~cm} \times 20 \mathrm{~cm})\end{array}$} & & & & & \\
\hline
\end{tabular}


Table.8 Effect of fertilizer levels (F) and plant geometry (S) on plant population after transplanting in ajowan

\begin{tabular}{|c|c|c|c|c|c|c|c|c|c|c|c|c|}
\hline \multirow{3}{*}{ Treatments } & \multicolumn{12}{|c|}{ Plant population after transplanting } \\
\hline & \multicolumn{4}{|c|}{30 days after transplanting } & \multicolumn{4}{|c|}{60 days after transplanting } & \multicolumn{4}{|c|}{90 days after transplanting } \\
\hline & $\mathrm{S}_{1}$ & $\mathrm{~S}_{2}$ & $\mathrm{~S}_{3}$ & Mean & $\mathrm{S}_{1}$ & $\mathrm{~S}_{2}$ & $\mathrm{~S}_{3}$ & Mean & $\mathrm{S}_{1}$ & $\mathrm{~S}_{2}$ & S3 & Mean \\
\hline $\mathbf{F}_{1}$ & 105.00 & 70.67 & 69.67 & 81.78 & 103.00 & 70.67 & 69.67 & 81.11 & 105.00 & 66.00 & 69.67 & 80.22 \\
\hline $\mathbf{F}_{2}$ & 104.33 & 70.00 & 70.67 & 81.67 & 104.33 & 70.00 & 70.67 & 81.67 & 102.33 & 70.00 & 70.67 & 81.00 \\
\hline $\mathbf{F}_{3}$ & 104.00 & 69.33 & 70.33 & 81.22 & 104.00 & 69.33 & 70.33 & 81.22 & 104.00 & 69.33 & 70.33 & 81.22 \\
\hline $\mathbf{F}_{4}$ & 104.67 & 69.00 & 70.33 & 81.33 & 104.67 & 69.00 & 70.33 & 81.33 & 104.67 & 69.00 & 70.33 & 81.33 \\
\hline $\mathbf{F}_{5}$ & 105.00 & 70.33 & 68.67 & 81.33 & 103.33 & 70.33 & 68.67 & 80.78 & 105.00 & 70.33 & 68.67 & 81.33 \\
\hline$F_{6}$ & 103.00 & 70.33 & 69.33 & 80.89 & 103.00 & 70.33 & 69.33 & 80.89 & 103.00 & 68.33 & 68.33 & 79.89 \\
\hline \multirow[t]{2}{*}{ Mean } & 104.33 & 69.94 & 69.83 & 81.37 & 103.72 & 69.94 & 69.83 & 81.16 & 104.00 & 68.83 & 69.67 & 80.33 \\
\hline & \multicolumn{2}{|c|}{$\mathbf{S} \mathbf{E m} \pm$} & \multicolumn{2}{|c|}{ CD at $5 \%$} & \multicolumn{2}{|c|}{ S Em \pm} & \multicolumn{2}{|c|}{ CD at $5 \%$} & \multicolumn{2}{|c|}{ S Em \pm} & \multicolumn{2}{|c|}{ CD at $5 \%$} \\
\hline $\mathbf{F}$ & \multicolumn{2}{|c|}{ NS } & \multirow{2}{*}{\multicolumn{2}{|c|}{$\begin{array}{l}\text { NS } \\
\text { NS }\end{array}$}} & \multicolumn{2}{|c|}{ NS } & & \multicolumn{2}{|c|}{ NS } & \multicolumn{2}{|c|}{ NS } \\
\hline $\mathbf{S}$ & \multicolumn{2}{|c|}{ NS } & & & \multicolumn{2}{|c|}{ NS } & \multicolumn{2}{|c|}{ NS } & $\mathrm{N}$ & & \multicolumn{2}{|c|}{ NS } \\
\hline F X S & \multicolumn{2}{|c|}{ NS } & \multicolumn{2}{|c|}{ NS } & & \multicolumn{2}{|c|}{ NS } & \multicolumn{2}{|c|}{ NS } & \multicolumn{2}{|c|}{ NS } \\
\hline \multicolumn{5}{|c|}{$\begin{array}{ll}\mathrm{F}=\text { Fertilizer level }(\mathrm{NPK} \mathrm{kg} \mathrm{ha} & -1 \\
\mathrm{~F}_{1}:(75 \% \mathrm{RDF}-15: 30: 15) & \mathrm{F}_{4}:(150 \% \mathrm{RDF}-30: 60: 30) \\
\mathrm{F}_{2}:(100 \% \mathrm{RDF}-20: 40: 20) & \mathrm{F}_{5}:(175 \% \text { RDF }-35: 70: 35) \\
\mathrm{F}_{3}:(125 \% \mathrm{RDF}-25: 50: 25) & \mathrm{F}_{6}:(200 \% \text { RDF- 40:80:40) }\end{array}$} & & $\begin{array}{l}\text { Plant geo } \\
(30 \mathrm{~cm} \mathrm{x} \\
(45 \mathrm{~cm} \mathrm{x} \\
(30 \mathrm{~cm} \mathrm{x}\end{array}$ & $\begin{array}{l}\text { try (spacir } \\
\mathrm{cm}) \\
\mathrm{cm}) \\
\mathrm{cm})\end{array}$ & & & & & \\
\hline
\end{tabular}




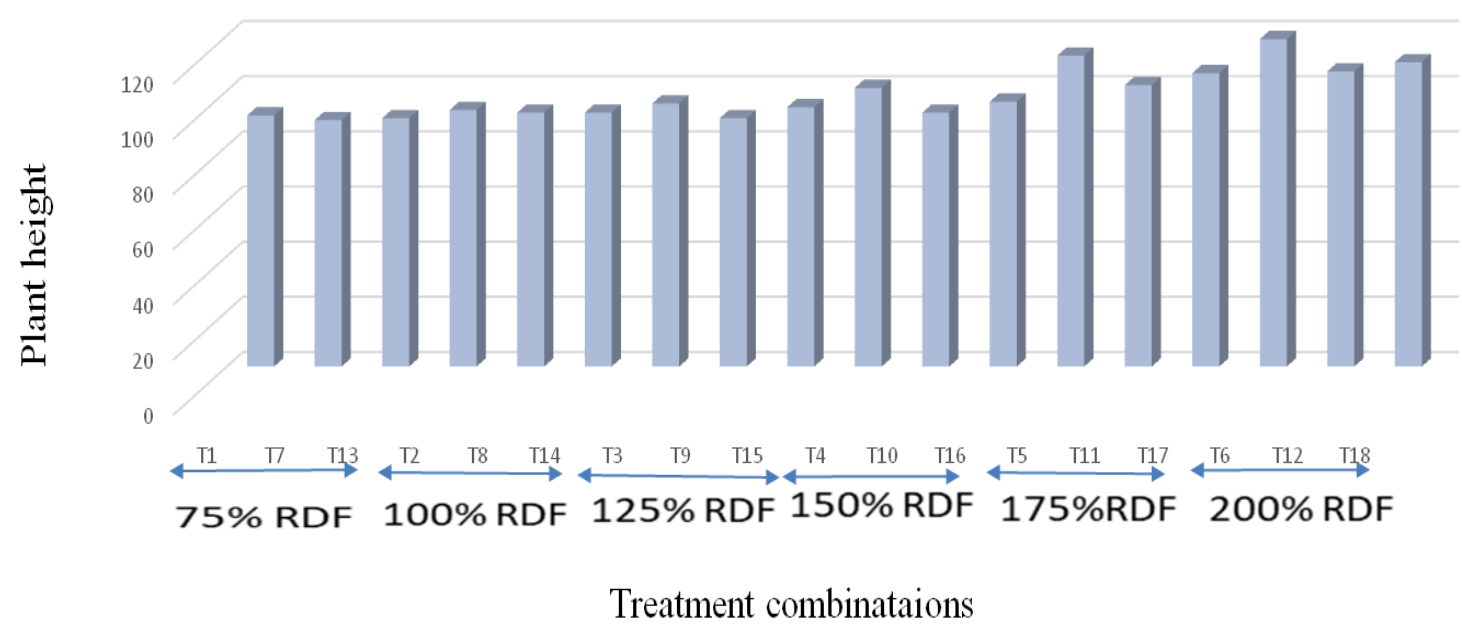

Fig.1 Effect of fertilizer levels (F) and plant geometry (S) on plant height in ajowan at 90 DAT

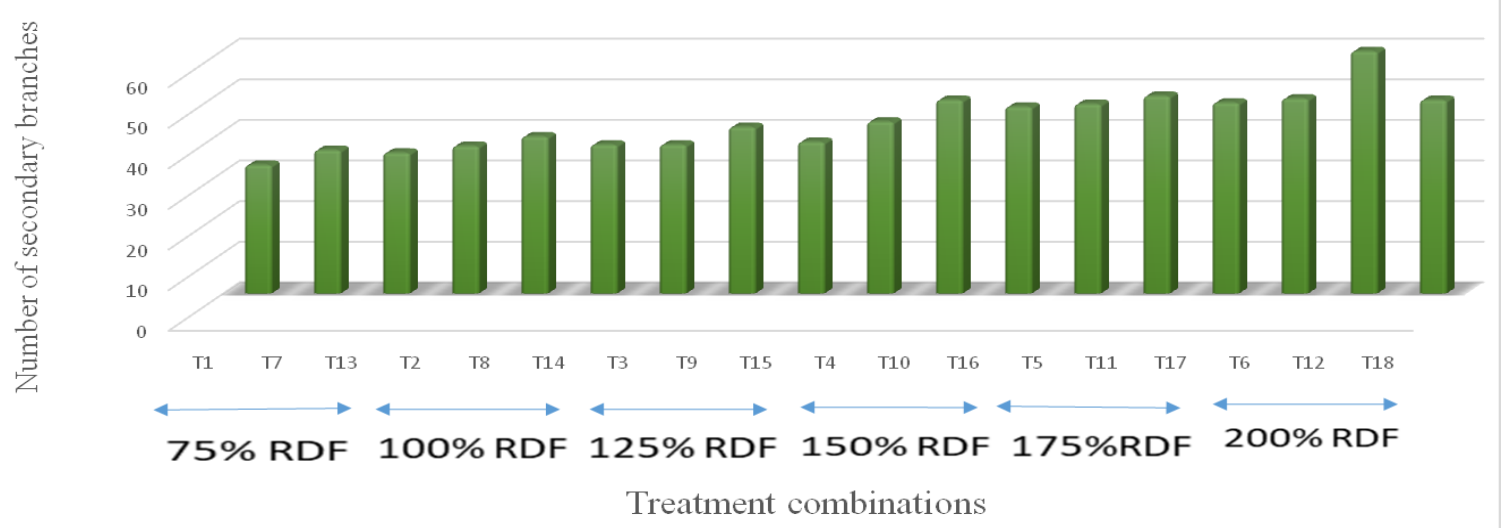

Fig.2 Effect of fertilizer levels (F) and plant geometry(S) on number of secondary branches in ajowan at 90 DAT

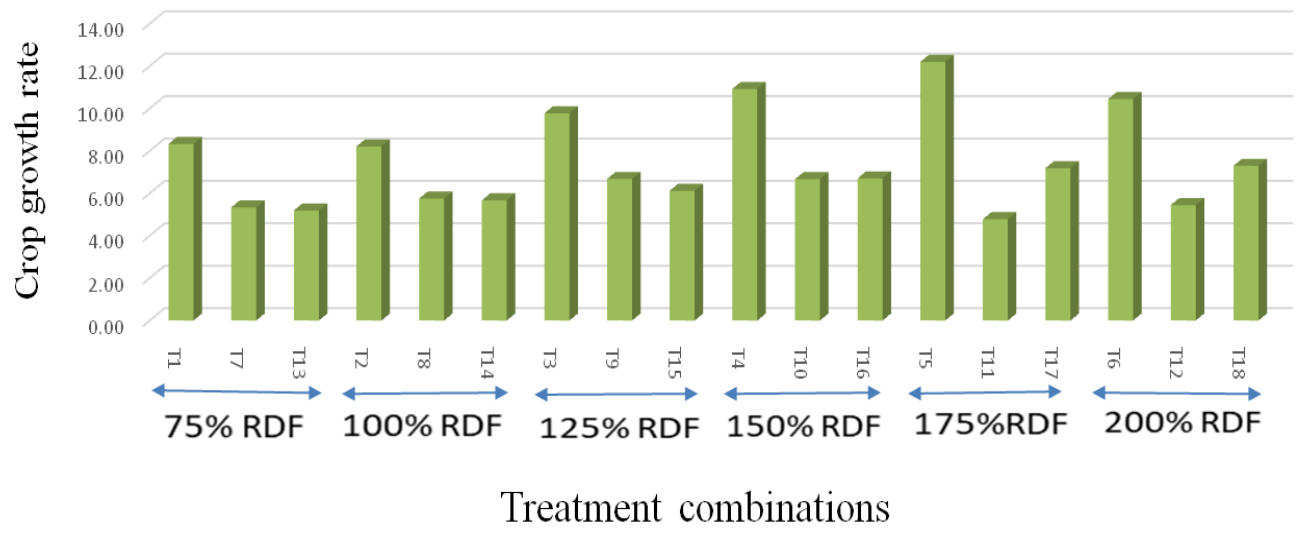

Fig.3 Effect of Fertilizer levels (F) and Plant geometry (S) on crop growth rate in ajowan at $90 \mathrm{DAT}$ 
Among the interaction effects between fertilizer levels and plant geometry, significantly increased dry weight (21.33, 34.00 and 48.67 at 30, 60 and 90 DAT respectively) was noticed with the application of 200\% RDF (40:80:40 NPK kg ha-1) with plant geometry $45 \mathrm{~cm} \times 20 \mathrm{~cm}$. The above results found that when plants grown under wider spacing increase in larger canopy development, increase in more number of primary and secondary branches and having less plant population compared to closer spacing which leads to more number of dry matter accumulation leads to more dry weight.

The above results indicated that with increase in application of fertilizer doses like nitrogen there will be increase in vegetative growth, photosynthesis activity leading to production of high photosynthates resulting in more dry matter accumulation.

The higher dry matter accumulation in the lower plant density was due to the decreased competition among the crop plants for various resources such as water, nutrients and light. Similar observations were found by Krishnamoorthy and Madalageri (2002).

\section{Crop growth rate $\left(\mathrm{g} \mathrm{dm}^{2} \mathrm{day}^{-1}\right)$}

The CGR recorded at 60 and 90 DAT was significantly influenced by the fertilizer doses, plant geometries and their interaction Table 7 and fig 3 . However, the effect of the treatments was non-significant at 30 DAT. Regarding fertilizer doses, at $60 \mathrm{DAT}$, the CGR was on par in all the fertilizer doses except for the dose of 150\% RDF (30:60:30 NPK kg ha ${ }^{-1}$ ) (3.06).

At 90 DAT, the CGR was on par with all the fertilizer doses evaluated except for the doses 75\% RDF (15:30:15 NPK kg ha $\left.{ }^{-1}\right)(6.28 \mathrm{~g}$ $\mathrm{dm}^{2}$ day $^{-1}$ ) and 100\% RDF (20:40:20 NPK kg $\left.\mathrm{ha}^{-1}\right) \quad\left(6.54 \mathrm{~g} \quad \mathrm{dm}^{2} \quad \mathrm{day}^{-1}\right)$ which were significantly lower than the other higher fertilizer doses. Among the different plant geometries evaluated, at 60 and 90 DAT, significantly higher CGR was observed with plant geometry of $30 \mathrm{~cm} \mathrm{x} 20 \mathrm{~cm}\left(4.8 \mathrm{~g} \mathrm{dm}^{2}\right.$ day $^{-1}$ and $9.98 \mathrm{~g} \mathrm{dm}^{2} \mathrm{day}^{-1}, 60$ DAT and 90 DAT respectively).

The differences in CGR in different fertilizer doses were mainly due to the differences in the production of growth in terms of branches and biomass per unit

At all stages of observation, significantly higher dry weight was recorded with $45 \mathrm{~cm} \mathrm{x}$ $20 \mathrm{~cm}(12.44,22.56$ and $38.17 \mathrm{~g}$ at 30,60 and 90 DAT, respectively) plant geometry over two other plant geometries. area. The higher CGR in increased plant densities was largely due to the increased dry matter production due to higher number of plants per unit area.

\section{Plant population after transplanting}

The data of plant population after transplanting are presented in the Table 4.8. The data related to plant population after transplanting with respect to fertilizer levels, plant geometry and their interaction was nonsignificant.

From the results obtained in the present investigation, it can be concluded that among the fertilizer levels and plant geometry significantly higher number of primary and secondary branches, fresh and dry weight per plant in the fertilizer level 200\% RDF and plant geometry $45 \mathrm{~cm} \times 20 \mathrm{~cm}$, plant height in the fertilizer level $200 \%$ RDF with the plant geometry $30 \mathrm{~cm} \times 20 \mathrm{~cm}$ and plant spread in the fertilizer level 200\% RDF with plant geometry $30 \mathrm{~cm} \times 30 \mathrm{~cm}$, crop growth rate at $175 \%$ RDF with plant geometry $30 \mathrm{~cm} \times 20$ $\mathrm{cm}$ but plant population after 30,60 and 90 days found non-significant. 


\section{References}

Balasubramaniyan, P. and Palaniappan, S. P. 2005. Principle and Practices of Agronomy. Publisher Agrobios, (India) Jodhpur. 158 - 85.

Donald, C.M. 1963. Competition among crop and pasture plants. Adv. Agron. 15: 1 118.

Jenny M. S, Vyakarnahal, S. J, Shekhargouda, B. S. and Patil, M. S. 2006. Influence of fertilizer and spacing levels on seed quality and its attributes in Ajowan. Karnataka Journal of Agricultural Science. 19 (1): 124 - 126.

Krishnamoorthy, V. and Madalagari, M. B. 2002. Effect of nitrogen and phosphorus on growth of ajowan genotypes (Trachyspermum ammi L.).

Naruka, I. S. Singh, P. P. Megha Barde, and Rathore S. S. 2012. Effect of spacing and nitrogen levels on growth, yield and quality of Ajowan (Trachyspermum ammi L.Sprague). International Journal Seed Spices. 2(1): 12 - 17.

NHB, 2016. Indian Horticulture Data Base. National Horticulture Board, Ministry of Agriculture, Government of India.Journal of Medicinal and
Aromatic Plant Science. 24 (1): 45 - 49.

Premnath, J. R. C. Verma, R.B.and Yadav G.C. 2008. Effect of date of sowing, nitrogen levels and spacing on growth and yield of Ajowan (Trachyspermum ammi L. Sprague). Journal of Spices and Aromatic Crops. 17 (1): 1 - 4.

Reddy, T.Y and Reddi, G.H.S. 2002. Principle of Agronomy. Kalyani Publishers Ludhiana. 214.

Sathyanarayana, E. Hadole, S. S. Laharia, G. S and Ghawade, S. M. 2015. Effect of nutrient levels on fertility status of soil and quality of ajwain (Trachyspermum ammi L. Sprague). International Journal of Tropical Agriculture 33: 3727 - 29.

Vavilov, N.I. and Dorofeev, V.F. 1992. Origin and geography of cultivated plants. Cambridge University Press.

Yadav, A.C. Yadav, J.S. Dhankhar, O.P. Avtar Singh and Singh, A. 2002. Yield and yield attributes of fennel (Foeniculum vulgare Mill.) as influenced by various row and plant spacings. Haryana Agricultural University Journal of Research. 32 (2): $81-83$.

\section{How to cite this article:}

Kiran. H. S., M. Lakshminarayana Reddy, K. Giridhar, S. Surya Kumari and Salomi Suneetha. D. R. 2020. Effect of Plant Geometry and Nutrition on Growth, Parameters of Transplanted Ajowan (Trachyspermum ammi L. Sprague) in the Red Loamy Soils of Andhra Pradesh, India. Int.J.Curr.Microbiol.App.Sci. 9(07): 871-886. doi: https://doi.org/10.20546/ijcmas.2020.907.101 